\title{
The Cause and Treatment of Atmospheric Pollution
}

\section{Wen-Xing ZHANG ${ }^{1, a}$, Ping DONG ${ }^{2, b}$ and Li-Min DONG ${ }^{3, c^{*}}$}

${ }^{1}$ Institute of Economics and business administration, Central China Normal University, Wuhan, Hubei, China

${ }^{2}$ Colorado State University, Colorado, the United States

${ }^{3}$ Instituteof Economics and business administration, Central China Normal University, Wuhan, Hubei, China

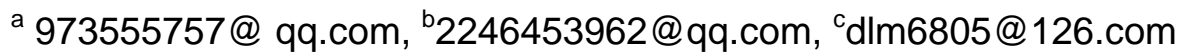

Keywords: Environmental policy; Air pollution control

\begin{abstract}
Environmental policy reform is still in a period of rapid advancement. This article takes Hubei Province as an example, according to the conditions of the province's percentage of fine weather, from the perspectives of GDP, population, exhaust emissions, number of environmental protection agencies, etc. And performs correlation and feature factor weight analysis; and based on the analysis results of the model, the environmental policy recommendations on atmospheric governance are proposed.
\end{abstract}

\section{Introduction}

With the development of society's production, environmental issues have attracted widespread attention. Countries around the world use different environmental policies to solve environmental problems in order to achieve sustainable development of the environment and economy. In the process of environmental governance, air pollution control cannot be ignored. Severe atmospheric pollution not only threatens the health of residents, but also affects the production and economic activities of the city's tourism industry, transportation, etc., and it is of great concern to the general public livelihood issues. However, atmospheric pollution is related to many factors. The article uses GBDT model to study the influencing factors of atmospheric pollution and the effectiveness of environmental protection in Hubei province from 2007 to 2015. Based on the results of the study, we propose corresponding policies for air pollution control.

\section{Analysis of Causes of Air Pollution in Hubei Province}

\section{Industrial Enterprise Exhaust Emissions}

With the advancement of the industrialization process, Hubei's three industrial restructurings in 2015 were 11.2: 45.7: 43.1, industrial output accounted for 46.7\% of the regional GDP, and the industrial share was relatively high. The main source of atmospheric pollutants is the exhaust gas produced during the industrial production process. The industrial production is based on the combustion of fossil fuels and the heavy use of chemical raw materials. The industrial exhaust gas contains smoke dust, sulfur dioxide, nitrogen oxides, smoke dust, and a large number of toxic gases. The emission of sulfur dioxide and nitrogen oxides from industrial waste gas in Hubei province has been declining year by year since 2011; sulfur dioxide emissions and nitrogen oxide emissions from industrial waste gas in Hubei Province in 2015 were 407.83 million tons and 381,969,000 tons, respectively. In addition, some enterprises consume large amounts of energy, use more industrial raw materials, and emit more exhaust gas. Enterprises discharge emissions for higher profits without treatment of exhaust gases, further aggravating atmospheric pollution.

\section{Urbanization Advancement}

Hubei Province has a large population and rapid economic development. In 2015, the urbanization rate reached $56.6 \%$, higher than the national average, leading the central region, and the urban population density continues to increase. With the increase of urban household garbage, more and 
more garbage disposal will affect the urban air quality. Urbanization has continued to advance; as the population has increased, major achievements have also been made in construction projects. Urban infrastructure investment construction and municipal construction have increased, the construction industry has been able to develop rapidly, and a large amount of dust has been generated during the construction process. In the process of urban infrastructure construction, the results have been emphasized, and there has been no effective protection of the urban ecological environment. In 2015, the total smoke and dust emissions in Hubei Province have reached 447,000 tons, which is very likely to cause environmental damage.

\section{Vehicle Exhaust Emissions}

Hubei Province is located in the most central location in China, with convenient transportation. Wuhan is even more popular in nine provinces. In 2015, the total amount of goods transported in Hubei was 1603.9306 million tons, of which the proportion of road freight transport reached $75.73 \%$, and along with the development of social production, people's living standards are constantly improving and the number of private cars is also gradually increasing. Whether it is cargo transportation or private car driving, it will generate a large amount of automobile exhaust. Major pollutants include nitrogen oxides, carbon monoxide, lead-containing compounds, and hydrocarbons. In 2015, the total particulate emission of motor vehicle exhaust in Hubei Province was 16,800 tons. The emissions of carbon monoxide, nitrogen oxides, and hydrocarbons from pollutants were 108.3, 18.09, and 126,300 tons, respectively. Exhaust gas composition is complex, there are more than 100 kinds of pollutants, it is very difficult to control after discharge, it will not cause serious impact on urban air quality, and directly harm the health of residents.

\section{Heating Pollution}

The percentage of good days in January and February 2015 in Hubei Province was only 16.8\% and $29.5 \%$, which was a lot different from the figures of $90.8 \%$ and $93.9 \%$ in the summer and July and August of the same year. Due to the low winter temperatures in Hubei and Increased use of heating equipment such as air conditioners, coal heating is still used in some areas, resulting in high pollutant emission concentrations and high strength. In the winter, the ground is a source of cold for the atmosphere, especially at night. The temperature of the atmosphere near the ground is lower than the temperature of the upper atmosphere, which results in the stability of the atmospheric stratification, the convection of air cannot be up and down, the accumulation of pollutants is difficult to spread, and the atmospheric pollution in winter is very serious.

\section{Model Design}

\section{Sample Selection and Data Collection}

This paper takes the atmospheric conditions of 17 key cities in Hubei Province as a sample, bases on the overall pollution discharge and environmental protection construction in the province, Data from 2007 to 2015 were collected from China Statistical Yearbook, China Environmental Protection Database, and Hubei Provincial Environmental Protection Department.

\section{Determination of Variables}

The paper selected the GDBT model for weighted analysis of the collected data, the percentage of fine weather can be used to measure the air quality of the city, the average annual average fine weather percentage of 17 major cities in Hubei Province from 2007 to 2015 was chosen as the explanation variable. The characteristic factors include the emissions of sulfur dioxide and nitrogen oxides from the industrial and domestic exhaust gases that cause atmospheric pollution; the provincial GDP and population that are relevant to the air quality. Our country is led by the government to control the atmosphere; the characteristic factors also include the number of investment in air pollution control and the construction of environmental protection infrastructure, as well as the number of environmental protection education activities. 


\section{Results Analysis}

According to the scores of the characteristic factors of the GBDT model, the percentage of good weather (the number of days with good grade weather in a year/the total number of days) can be used as an indicator to measure the quality of air quality in Hubei Province, the emission of sulfur dioxide in industrial waste gas has the greatest impact on air quality, the two characteristics of GDP and population in Hubei Province also play a greater role in the air quality of Hubei Province. In terms of environmental protection policy,the total amount of environmental protection investment for the approval of construction projects has a significant impact on air quality. The area of nature reserves and the number of publicity and education activities in social bad environment also have a certain influence. The effect of other characteristic factors is not significant.

Feature Table

\begin{tabular}{|c|c|c|c|}
\hline $\begin{array}{l}\text { Explained } \\
\text { variables }\end{array}$ & \multicolumn{3}{|c|}{ Hundreds of days with good air quality in Hubei Province } \\
\hline \multirow{6}{*}{$\begin{array}{c}\text { Characteristic } \\
\text { Factors }\end{array}$} & $\begin{array}{l}\text { [1] Total Industrial } \\
\text { Emissions (0.007) }\end{array}$ & $\begin{array}{l}\text { [7] Hubei Province GDP } \\
\text { (0.213) }\end{array}$ & $\begin{array}{l}\text { [13] Hubei Province } \\
\text { Population (0.249) }\end{array}$ \\
\hline & $\begin{array}{l}\text { [2] Sulfur dioxide } \\
\text { emissions from industrial } \\
\text { waste gas } \\
(0.253)\end{array}$ & $\begin{array}{c}\text { [8] Major Pollutant Treatment } \\
\text { Facilities } \\
\text { Handling operating costs } \\
\text { (industrial waste gas) } \\
(0.0055)\end{array}$ & $\begin{array}{c}\text { [14] Nature Reserve } \\
\text { Area } \\
(0.0279)\end{array}$ \\
\hline & $\begin{array}{c}\text { [3] Industrial exhaust } \\
\text { nitrogen oxide emissions } \\
\text { (0.0039) }\end{array}$ & $\begin{array}{c}\text { [9] Total Investment in Urban } \\
\text { Environmental Infrastructure } \\
\text { Construction } \\
(0.0033)\end{array}$ & $\begin{array}{c}\text { [15] Developing Social } \\
\text { Environment } \\
\text { Publicity and } \\
\text { educational activities } \\
(0.0277) \\
\end{array}$ \\
\hline & $\begin{array}{l}\text { [4] Sulfur dioxide } \\
\text { emissions from domestic } \\
\text { waste } \\
(0.0045)\end{array}$ & $\begin{array}{c}\text { [10] Total Investment in } \\
\text { Environmental Pollution } \\
\text { Control } \\
(0.0037)\end{array}$ & $\begin{array}{c}\text { [16] Number of Waste } \\
\text { Gas Treatment } \\
\text { Construction Projects } \\
(0.0062)\end{array}$ \\
\hline & $\begin{array}{c}\text { [5] Domestic waste } \\
\text { nitrogen oxide emissions } \\
(0.0025)\end{array}$ & $\begin{array}{l}\text { [11] Approve the total amount } \\
\text { of environmental protection } \\
\text { investment in construction } \\
\text { projects } \\
(0.181)\end{array}$ & $\begin{array}{l}\text { [17] Number of } \\
\text { Environmental } \\
\text { Protection System } \\
\text { Organizations } \\
(0.0088)\end{array}$ \\
\hline & $\begin{array}{c}\text { [6] Major pollutant } \\
\text { treatment facilities } \\
\text { Processing capacity } \\
\text { (industrial exhaust gas) } \\
\text { (0.0005) }\end{array}$ & $\begin{array}{l}\text { [12] Environmental Monitoring } \\
\text { Operation Funds } \\
(0.0023)\end{array}$ & \\
\hline
\end{tabular}

GBDT model feature factor score 


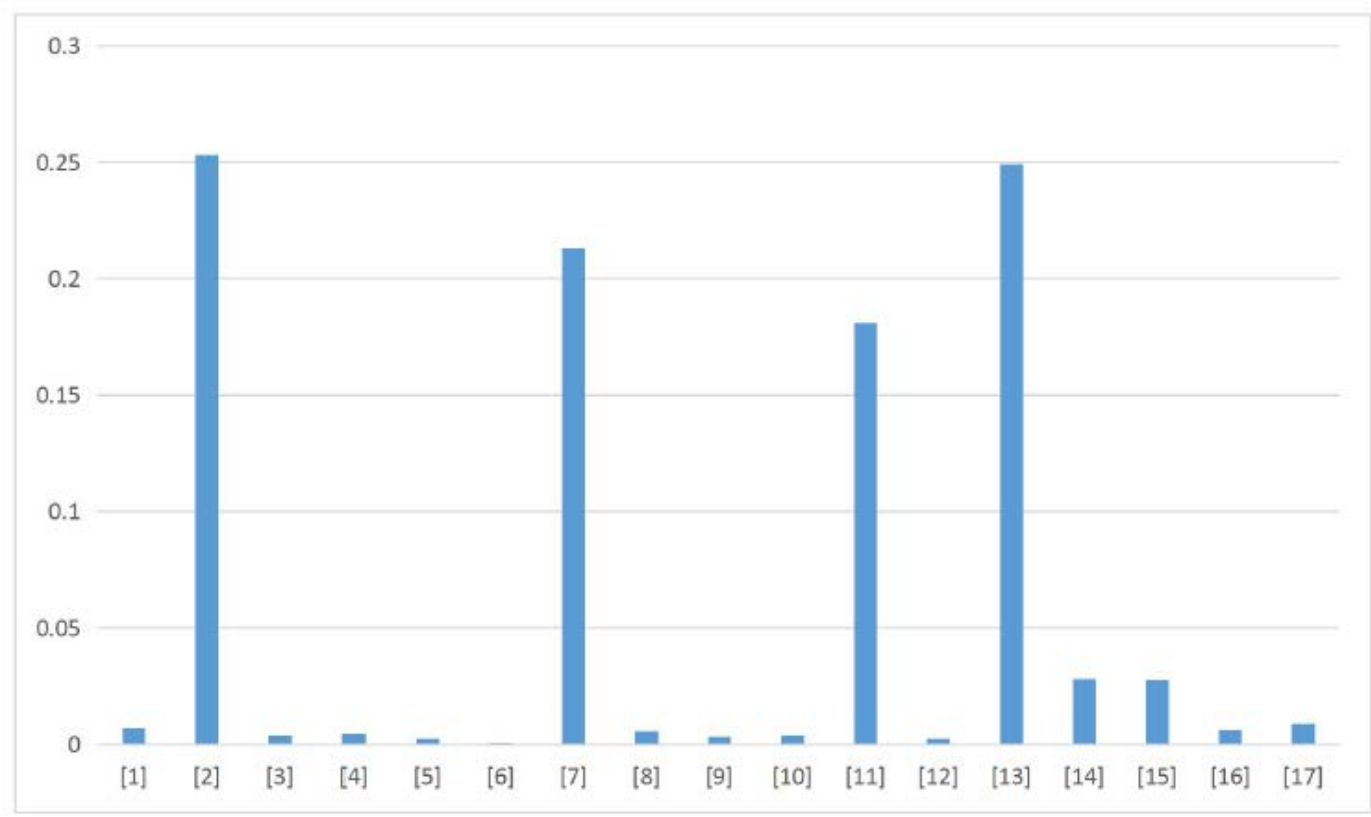

Fig. 1

\section{Conclusion and Suggestion}

\section{Control Industrial Emissions}

According to the model score results, the characteristic factor of sulfur dioxide emissions in industrial waste gas was 0.253 , which had the greatest impact on the air quality. In the process of regional development, the government must adhere to the strategy of sustainable development, adjust and optimize the industrial structure, promote industrial transformation and upgrading, strictly control new production capacity in high-energy-consuming and highly polluting industries, and accelerate the elimination of backward production capacity. For the highly polluting industries, we must accelerate the development of desulfurization, denitrification, dust removal, and renovation projects, and conduct comprehensive supervision of the production process of enterprises to reduce the discharge of multiple pollutants.

\section{Comprehensively Rectify the Emission of Exhaust Gas and Dust from Cities}

In the process of municipal construction, we must strengthen the supervision of construction dust control and actively promote green construction. Construction sites should be completely enclosed and fence walls must be set up, and open operations are strictly prohibited. The nature of the area of nature reserves is rated at 0.0279 in the model, so it can also promote the construction of urban and surrounding afforestation and windbreak and sand prevention forests, and expand the scale of green areas in urban built-up areas.

\section{Reduce Vehicle Exhaust Emissions}

The development of public transportation will encourage the public to travel by public transport and city railways. At the same time, private cars can be subject to limit number management, which will reduce the use of private cars. The government should strengthen the management of exhaust emissions from motor vehicles, develop motor vehicles based on clean energy, and research and develop devices for handling vehicle exhaust gases.(Because the vehicle exhaust data is missing, it is not reflected in the model)

\section{Extensive Environmental Education}

From the GDBT model, it can be seen that the total environmental protection investment rating of the approval construction project is 0.181 , and the number of public environmental education activities conducted is 0.0277 , which has a greater effect on the air quality. In the process of 
atmospheric management, the government should increase investment in environmental protection construction projects and at the same time carry out environmental education for the general public to increase residents' awareness of energy conservation and environmental protection.

\section{Acknowledgements}

Correspovding arthor: Limin Dong (dlm6805@126.com)

\section{References:}

[1]Zhi Zhang, Caifeng Yuan, Xiangming Shi. Research on the causes of atmospheric pollution in Zhengzhou City and its prevention and control strategies [J]. Environment and Sustainable Development, 2017, 42(4): 180-181.

[2]Lu Zhao. Motor Vehicle Exhaust Pollution and Its Mitigation Measures [J]. Environmental Science and Management, 2008, 33(5):87-88.

[3]Xiuyan Zhang. Analysis of atmospheric environmental pollution factors and their control measures [J]. Science \& Technology Wind, 2018(4):108-108.

[4]Guangxie Li. Study on the Transformation of Industrial Structure in Hubei Province Based on VAR Model [J]. Statistics and Decision, 2017(1):145-148.

[5] Nan Chen, Yu Li, Zhongmei Cao, et al. Study on the level of atmospheric particulate pollution and the correlation of pollutants in Hubei[J]. Environmental Science and Technology, 2016(9): 194-198. 